\title{
ANALISIS KEPUASAN MASYARAKAT ATAS KUALITAS PELAYANAN KEPOLISIAN PADA KANTOR DIREKTORAT INTELIJEN KEAMANAN POLISI DAERAH BENGKULU
}

\author{
Hendra Kusuma \\ Direktorat Intelijen Keamanan Polisi Daerah Bengkulu \\ Merri Anitasari \\ Dosen Fakultas Ekonomi dan Bisnis Universitas Bengkulu
}

\begin{abstract}
ABSTRAK
Hendra Kusuma, Merri Anitasari; Tujuan penelitian ini adalah untuk mengetahui pelayanan pada kantor Direktorat Intelijen Keamanan Polisi Daerah Bengkulu. Metode pengumpulan data yang digunakan adalah kuisioner. Metode analisis yang digunakan adalah Indeks Kepuasan Masyarakat. Berdasarkan hasil penelitian dan analisa data tentang analisis pelayanan pada Direktorat Intelijen Keamanan Polisi Daerah Bengkulu, maka dapat ditarik suatu kesimpulan bahwa nilai rata-rata per unsur pelayanan yang paling tinggi adalah pada kejelasan petugas pelayanan yang diberikan oleh Direktorat Intelijen Keamanan Polisi Daerah Bengkulu yaitu dengan nilai unsure pelayanan sebesar 2,77 dan nilai rata-rata per unsur pelayanan yang paling rendah yaitu pada kepastian biaya sebesar 2,41. Nilai IKM pada Direktorat Intelijen Keamanan Polisi Daerah Bengkulu sebesar 63,9 yang berarti bahwa kinerja unit pelayanan pada Direktorat Intelijen Keamanan Polisi Daerah Bengkulu adalah "baik", karena nilai tersebut berada diantara 62,51 - 81,25 yang berada pada mutu pelayanan B (baik).
\end{abstract}

\begin{abstract}
Hendra Kusuma, Merri Anitasari; Purpose of this study was to determine the intelligence directorate office services at the regional police security Bengkulu. Method data collecting the used is questionnaire. Analysis method the used is Index Satisfaction of Society. Pursuant to result of data analysis and research about service analysis at intelligence directorate office services at the regional police security Bengkulu, hence can be pulled an conclusion that average value per highest service element is clarity care workers of service given by intelligence directorate office services at the regional police security Bengkulu that is with value of unsure service equal to 2,77 and average value per lowest service element that is at certainty of expense equal to 2,41. Value of IKM at intelligence directorate office services at the regional police security Bengkulu equal to 63,9 meaning that service unit performance at intelligence directorate office services at the regional police security Bengkulu is "goodness", because the value reside in among 62,51 - 81,25 residing in a quality of service of $B$ (good).
\end{abstract}

Key words: Service Quality

\section{PENDAHULUAN}

Manusia pada dasarnya makhluk social yang tidak dapat hidup tanpa bantuan orang lain. Oleh karena itu manusia dituntut untuk mampu berinteraksi dan hidup berdampingan dengan sesame dan juga harus mampu melakukan berbagai penyesuaian, baik penyesuaian yang bersifat individu maupun penyesuaian yang bersifat normatif. Hal ini dilakukan agar dapat tercipta hubungan yang sehat dalam masyarakat mencakup penyesuaian terhadap peraturan, baik yang tertulis maupun tidak tertulis. Ketidakmampuan menyesuaikan diri dengan lingkungan sosial akan mengakibatkan permasalahan dalam masyarakat, seperti terjadinya berbagai macam pelanggaran, tindak kejahatan, perselisihan dan lain-lain.

Dalam mengatasi berbagai macam permasalahan yang terjadi di kalangan masyarakat, maka otomatis suatu Negara membutuhkan suatu lembaga yang bertugas untuk 
menyelenggarakan keamanan dan ketertiban umum. Di Indonesia khususnya, lembaga yang betugas menjalankan fungsi tersebut adalah Kepolisian Negara Republik Indonesia (POLRI). Dalam hal ini POLRI bertugas untuk menjaga keamanan Negara dan menegakkan hukum yang berlaku di wilayah Indonesia. Menjaga keamanan dan ketertiban bukan hanya tugas dari seorang polisi atau lembaga kepolisian, namun diperlukan kerjasama juga antara masyarakat dengan aparat kepolisian yang berwenang. Lembaga kepolisian adalah sebagai penyelenggaraan pelayanan publik yang mana merupakan salah satu fungsi penting pemerintah disamping distribusi, regulasi, dan proteksi. Fungsi tersebut merupakan aktualisasi riil kontrak sosial yang diberikan masyarakat kepada pemerintah.

Pelayanan publik yang diberikan instansi Pemerintah (Pusat, Pemerintah Propinsi, Kabupaten, Kota dan Kecamatan) kepada masyarakat merupakan perwujudan fungsi aparatur negara sebagai abdi masyarakat. Pada era otonomi daerah, fungsi pelayanan publik menjadi salah satu fokus perhatian dalam peningkatan kinerja instansi pemerintah daerah. Oleh karenanya secara otomatis berbagai fasilitas pelayanan publik harus lebih didekatkan pada masyarakat, sehingga mudah dijangkau oleh masyarakat. Pemerintah Pusat mengeluarkan sejumlah kebijakan untuk meningkatkan kinerja instansi pemerintah dan kualitas pelayanan publik, antara lain kebijakan tentang Penyusunan Sistem dan Prosedur Kegiatan, Penyusunan Akuntabilitas Kinerja Instansi Pemerintah (Inpres No. 7 Tahun 1999), dan Pedoman Umum Penyusunan Indeks Kepuasan Masyarakat Unit Pelayanan Instansi Pemerintah (SK Menpan No. KEP/25/M.PAN/2/2004). Langkah ini sebenarnya bukanlah hal baru, karena sebelumnya kebijakan serupa telah dikeluarkan pemerintah dalam bentuk Keputusan Menpan maupun Instruksi Presiden (Inpres). Kebijakan itu ternyata tidak secara otomatis menyelesaikan permasalahan pelayanan publik oleh instansi pemerintah yang selama ini bercitra buruk, berbelit-belit, lamban, dan berbiaya mahal. Hal tersebut berkaitan dengan persoalan seberapa jauh berbagai peraturan pemerintah tersebut disosialisasikan di kalangan aparatur pemerintah dan masyarakat, serta bagaimana infrastruktur pemerintahan, dana, sarana, teknologi, kompetensi sumberdaya manusia, budaya kerja organisasi disiapkan untuk menopang pelaksanaan berbagai peraturan tersebut, sehingga kinerja pelayanan publik menjadi terukur dan dapat dievaluasi keberhasilannya.

Kantor Direktorat Intelijen Keamanan Polisi Daerah Bengkulu dalam hal ini, memberikan pelayanan kepada masyarakat dalam hal perizinan dan pemberitahuan kegiatan masyarakat serta penerbitan surat keterangan catatan kepolisian. Dilihat dari banyaknya masyarakat yang berkepentingan untuk membuat perizinan serta surat keterangan catatan kepolisian maka penulis tertarik untuk melakukan penelitian dalam rangka membuat skripsi dengan judul : "Analisis Kepuasan Masyarakat Atas Kualitas Pelayanan Kepolisian Pada Kantor Direktorat Intelijen Keamanan Polisi Daerah Bengkulu".

\section{Landasan Teori Pelayanan}

Menurut Hasibuan (2005:152), pelayanan adalah : "kegiatan pemberian jasa dari suatu pihak kepada pihak lainnya". Pelayanan yang baik adalah pelayanan yang dilakukan secara ramah tamah, adil, cepat, dan dengan etika yang baik sehingga memenuhi kebutuhan dan kepuasan bagi yang menerimanya.

a. Ramah tamah dimaksudkan bahwa pelayanan yang dilakukan dengan wajah ceria, wajar, dan dengan etika yang baik serta tidak menyinggung perasaan.

b. Adil artinya pelayanan yang diberikan berdasarkan urutan antrian.

c. Cepat dan tepat dimaksudkan pelayanan yang diberikan tidak bertele-tele dan harus baik dan benar.

d. Etika adalah suatu sistem moral perilaku berdasarkan peraturan dan norma-norma sosial, budaya dan agama yang berlaku dalam suatu masyarakat.

Sedangkan menurut Tjiptono (2008:1) secara sederhana, istilah service mungkin bisa diartikan sebagai "melakukan sesuatu bagi orang lain". Setidaknya ada tiga kata yang bias mengacu pada istilah tersebut, yakni jasa, pelayanan, dan servis. Sebagai jasa, service umumya 
mencerminkan produk tidak berwujud fisik (intangible) atau sektor industri spesifik, seperti pendidikan, perbankan dll. Sebagai layanan, istilah service menyiratkan segala sesuatu yang dilakukan pihak tertentu (individu maupun kelompok) kepada pihak lain (individu maupun kelompok), salah satu contohnya adalah layanan pelanggan (customer service). Sementara itu kata servis lebih mengacu pada konteks reparasi, seperti servis sepeda motor.

Dalam Tjiptono (2008:3) dijumpai setidaknya empat lingkup definisi konsep service :

a. Service menggambarkan berbagai subsektor dalam kategorisasi aktivitas ekonomi, seperti transfortasi, finasial, perdagangan ritel, pendidikan dan layanan publik. Dengan kata lain lingkupnya adalah industri.

b. Service dipandang sebagai produk intangible yang hasilnya lebih berupa aktivitas ketimbang obyek fisik, meskipun dalam kenyataannya bisa saja produk fisik dilibatkan (umpamanya, makanan, minuman di restoran dan pesawat di jasa penerbangan). Jadi, dalam hal ini lingkupnya adalah tawaran produk.

c. Service merefleksikan proses, yang mencakup penyampaian produk utama, interaksi personal, kinerja dalam arti luas (termasuk didalamnya drama dan keterampilan), serta pengalaman layanan.

d. Service bisa pula dipandang sebagai sebuah sistem yang terdiri atas dua kompenen utama, yakni service operations yang kerap kali tidak tampak atau tidak diketahui keberadaannya oleh pelanggan dan service delivery yang biasanya tampak (visible) atau diketahui pelanggan.

Menurut Tjiptono (2008:5) berkembangnya berbagai perspektif menyangkut definisi service menunjukkan secara gamblang signifikansi dan dinamika service dalam kacah perekonomian dunia. Hal ini terutama dipicu oleh tiga faktor :

a. Pertumbuhan sektor jasa berlangsung pesat dalam beberapa dekade terakhir. Semakin hari, semakin banyak bermunculan jenis-jenis jasa baru dan inovatif. Perkembangan sektor jasa tidak bisa lepas dari tahap-tahap perkembangan aktivitas perekonomian yang terdiri atas lima tahap : (1) tahap primer (ekstraktif), meliputi pertanian, pertambangan, perikanan, dan kehutanan; (2) tahap sekunder (produksi barang), meliputi pemanufakturan dan pemerosesan; (3) tahap tersier (jasa domestik), terdiri atas restoran dan hotel dll. ; (4) tahap kuarter (perdagangan), meliputi transportasi, perdagangan ritel, komunikasi, keuangan dan asuransi dan pemerintahan; (5) tahap kuiner (perbaikan dan peningkatan kapasitas manusia), terdiri atas kesehatan, pendidikan, rekreasi, dll. Tahap tersier, kuarter dan kuriner pada hakikatnya mencerminkan sektor jasa, sehingga kalau ketiganya digabungkan akan menghasilkan tiga tahap utama; primer (ekstraktif), sekunder (produksi barang), dan tersier (jasa).

b. Faktor layanan telah bertumbuh pesat sebagai diferensiator dan kunci keunggulan bersaing. Bila ditinjau dari sudut pandang perusahaan, salah satu cara efektif untuk melakukan diferensiasi dan positioning unik adalah melalui perancangan dan penyampaian layanan spesifik. Hal ini dampak strategis pada strategi bersaing perusahaan. Sebagai contoh, bisnis utama restoran bergeser dari sekedar menyediakan menu hidangan (makanan dan minuman) untuk dijual, menjadi usaha melayani dan memuaskan rasa lapar para pelanggan dengan disertai usaha menyediakan suasana yang nyaman bagi merka dalam menyantap hidangan.

c. Disadari atau tidak, setiap bisnis pada hakikatnya adalah bisnis jasa/-

layanan. Di dalam setiap organisasi, misalnya, dikenal adanya istilah

pelanggan internal (karyawan). Dengan kata lain, setiap individu atau departemen berperan sebagai penyedia maupun penerima layanan individu/departemen lainnya. Kualitas layanan yang diberikan kepada pelanggan eksternal sangat bergantung pada kualitas relasi dan kerja sama pelanggan internal. Oleh sebab itu kepuasan dan loyalitas pelanggan internal tercipta.

Lebih lanjut, sejumlah pakar pemasaran bahkan menegaskan bahwa kini telah terjadi pergeseran pradigma, dari yang semula Good Dominant Logic (GDL) menjadi Service Dominant Logic (SDL). Secara ringkas, esensi pemikiran SDL adalah penyediaan layanan/jasa merupakan tujuan fundamental dari pertukaran ekonomi dan pemasaran. Dengan kata lain, individu 
maupun kelompok (organisasi) saling mempertukarkan layanan/jasa. Sementara barang, uang, organisasi dan jejaring meruapakan perantara (intermadiaries) atau institusi tambahan (collateral institutions) dalam proses pertukaran layanan/jasa dengan layanan/jasa. Dalam konteks ini, layanan/jasa, layanan/jasa dirumuskan sebagai aplikasi kompetensi (pengetahuan dan keterampilan) terpesialisasi melalui perbuatan/tin-dakan, proses, dan kinerja demi manfaat bagi entitas bersangkutan atau entitas lain.

Agar pelayanan yang diberikan berkualitas tentu saja kedua kualitas di atas dimaksudkan untuk dipenuhi, begara berkembang umumnya tidak dapat memenuhi kedua kualitas tersebut sehingga pelayanan publiknya menjadi kurang memuaskan. Hambatan dalam sistem manajemen kualitas antara lain sebagai berikut (Julianta dalam Sinambela, 2010:6) :

1. Ketiadaan komitmen dari manajemen.

2. Ketiadaan pengetahuan dan kekurangpahaman tentang manajemen kualitas bagi aparatur yang bertugas melayani.

3. Ketidakmampuan aparatur mengubah kultur yang mempengaruhi kualitas manajemen pelayanan pelanggan.

4. Ketidaktepatan perencanaan manajemen kualitas yang dijadikan pedoman dalam pelayanan pelanggan.

5. Pendidikan dan pelatihan yang berkelanjutan belum dioptimalkan.

6. Ketidaksesuaian antara struktur organisasi dengan kebutuhan.

7. Ketidakcukupan sumber daya dan dana.

8. Ketidaktepatan sistem penghargaan dan balas jasa bagi karyawan.

Selanjutnya menurut Tjipono (2008:148) mengemukakan ada lima dimensi pokok/indikator yang berpengaruh dalam penilaian pelayanan yaitu :

1. Tangibles (tampilan fisik), merupakan penampilan dan kemampuan langsung dari sarana dan prasarana fisik yang meliputi fasilitas fisik perlengkapan, karyawan dan sarana komunikasi.

2. Reability (kehandalan), kemampuan perusahaan untuk memberikan pelayanan yang disajikan dengan segera, akurat dan terpercaya.

3. Responssivenmes (ketanggapan), keinginan untuk membantu pelanggan dan memberikan pelayanan yang tanggap.

4. Assurance (jaminan), mencakup pengetahuan, kompetensi, kesopanan dan aspek terhadap pelanggan serta kemampuan melaksanakan tugas secara spontan yang dapat menjamin kinerja yang baik sehingga kepercayaan dan keyakinan pelanggan.

5. Empathy (empati), memberikan perhatian yang bersifat individuali atau pribadi secara tulus kepada pelanggan dan kemudahan dalam melakukan hubungan komunikasi serta berupaya untuk memahami keinginan dan kebutuhan pelanggan.

\section{Bentuk-Bentuk Pelayanan}

Penawaran sebuah perusahaan kepada konsumen maupun calon konsumen biasanya mencakup sejumlah bentuk layanan. Komponen layan tersebut bias jadi hanyalah sebagain kecil ataupun bagian uatam/pokok dari keseluruhan penawaran berangkutan. Pada kenyataannya, sebuah penawaran dapat bervariasi di antara dua kutub ekstrim, yaitu murni berupa barang pada satu sisi dan jasa murni pada sisi lainnya. lima kategori

Menurut Tjiptono (2008:8) penawaran sebuah perusahaan dapat dibedakan menjadi

a. Barang fisik murni : penawaran pada kategori ini semata-mata hanya berupa barang fisik.

b. Barang fisik dengan jasa pendukung : pada kategori ini, penawaran terdiri atas barang fisik yang disertai dengan satu atau beberapa bentuk layanan guna meningkatkan daya tarik pada konsumen.

c. Produk hybrid : penawaran pada kategori ini terdiri atas komponen barang dan layanan yang relatif seimbang porsinya.

d. Jasa utama yang didukung dengan barang minor : penawaran pada kategori ini terdiri atas jasa pokok tertentu bersama-sama dengan barang-barang pendukung.

e. Jasa murni : penawaran pada kategori ini hampir seluruhnya berupa jasa. 
Konsekuensi logis dari adanya berbagai macam variasi kombinasi antara barang dan jasa adalah sulit menggeneralisasikan layanan/jasa tanpa melakukan perbedaan lebih lanjut. Setidaknya delapan kriteria klasifikasi layanan/jasa berikut ini paling banyak digunakan, yaitu :

a. Segmen pasar

Berdasarkan segmen pasar, jasa dapat dibedakan menjadi jasa/layanan yang ditujukan pada konsumen akhir, dan jasa/layanan bagi konsumen organisasional. Perbedaan utama antara keduanya terletak pada alasan/motif pembelian dan kriteria spesifik dalam memlilih jasa dan penyedia jasa, kuantitas jasa ynag dibutuhkan, dan kompleksitas pengerjaan jasa yang diperlukan. Umumnya proses keputusan pembelian yang dilakukan konsumen organisasional lebih rumit dibandingkan dengan konsumen akhir.

b. Tingkat keberwujudan

Kriteria ini berhubungan dengan tingkat keterlibatan produk fisik dengan konsumen. Berdasarkan kriteria ini, jasa/layanan dapat dipilahkan menjdai tiga macam ;

1) Rented-goods service

Dalam tipe ini, konsumen menyewa dan menggunakan produk tertentu berdasarkan tarif yang disepakati selama jangka waktu spesifik.

2) Owned goods services

Pada tipe ini, produk-produk yang dimiliki konsumen direprasi, dikemabngkan atau diitingkatkan unjuk kerjanya, atau dipelihara/dirawat oleh perusahaan jasa. Jenis jasa seperti ini juga mencakup perubahan bentuk pada produk yang dimiliki konsumen.

3) Non goods services

Karakteristik khusus pada jenis ini adalah layanan personal

bersifat intangible (tidak berbentuk produk fisik) ditawarkan kepada pelanggan.

Dalam kaitannya dengan aspek pemasaran, secara umum dapat dikatakan bahwa semakin tidak berwujud jasa/layanan, maka semakin sedikit kesamaan antara pemasaran jasa dan pemasaran barang berwujud. Pada non good service, misalnya, kinerja (performance) hanya dapat dinilai setelah jasa disampaikan dan konsistensi kinerja bersangkutan sulit dijaga. Sebaliknya, rented goods services dan owned goods services dapat dipasarkan dengan cara-cara yang serupa dengan pemasaran barang berwujud (produk fisik), karena kedua tipe jasa ini memerlukan barng-barang fisik dan lebih bersifat tangible.

c. Keterampilan penyedia jasa/layanan

Berdasarkan tingkt keterampilan penyeidia jasa/layanan, terdapat dua tipe pokok jasa: profesoinal service dan non profesional service. Perbdeaan pokok diantara kedua tipe tersebut adalah jasa profesional biasanya menuntut tingkat pendidikan formal tertentu dari para penyeida layanan dan bahkan banyak di antaranya memiliki asosiasi profesi sendiri-sendiri. Pada jasa yang membtuhkan keterampilan tinggi dalam proses operasinya, pelanggan cenderung sangat selektif dan berhati-hati dalam memilih penyedia jasa. Hal inilah yang menyebabkan para penyedia jasa profesional dapat mengikat para pelanggannya. Sebaliknya, jika jasa tidak memerlukan keterampilan tinggi, sering kali loyalitas pelanggan rendah karena penawarannya sangat banyak dan acap kali tidak berbeda secara signifikan.

d. Tujuan organisasi jasa

Berdasarkan tujuan organisasi, jasa/layanan dapat diklasifi-kasikan menjadi; commercial services atau profit services (misalnya jasa penerbangan, bank, hotel) dan nonprofit services (misalnya sekolah, yayasan, panti asuhan, istanasi pemerintah)

e. Tingkat regulasi

Dari aspek regulasi, jasa dapat dibagi menjadi regulated servces (misalnya jasa pilang, akuntan, rumah sakit, penerbangan, penerbangan) dan non-regulated servcies (seperti jasa makelar, katering, pondokan, asrama, kantion).

f. Tingkat intensitas karyawan

Berdasarkan tingkat intensitas karyawan (keterlibatan tenaga kerja), layanan dapat dikelompokkan menjadi dua macam: equipment-based services (seperti cuci mobil otomatis, 
mesin ATM, dll) dan people-based services (seperti pelatih renang, satpam, akuntan, dll). Layanan padat karya (people-based services) biasanya dijumpai pada peruahaan yang memang memerlukan banyak tenaga ahli dan apabila penyampaian layanan itu harus dilakukan di tempat tingggal atau di tempat usaha pelanggan. Layanan juga akan bersifat padat karya apabila proses penyampaiannnya kepada satu orang pelanggan tertentu memakan waktu cukup lama, sehingga perusahaan membutuhkan staf yang relatif banyak agar mampu melayani pelanggan lainnya pada saat bersamaan. Sementara itu, perusahaan yang bersifat equipment-based services mengedepankan penggunaan mesin dan peraltan canggih yang dapat dikendalikan dan dipantau secara otomatis atau semi-otomatis. Ini dilakukan dengan tujuan untuk menjaga konsistensi kualitas layanan yang diberikan dan meningkatkan efisiensi.

g. Tingkat kontak penyedia layanan pelanggan

Berdasarkan tingkat kontak ini, secara umum layanan dapat dikelompokkan mejadi high-contact services (seperti universitas, dokter, penata rambut, pegadaian, dan konsultan bisnis), dan low-contact services (misalnya bioskop, swalayan, jasa Direktorat Intelijen Keamanan Polisi Daerah Bengkulu, jasa telekomunikasi, dan jasa layanan pos).

h. Manfaat bagi konsumen

Dalam hal ini, layanan bisa dibedakan menjadi dua macam. Pertama, for-consumer (facilitating services), yaitu layanan yang dimanfaatkan sebagai sarana atau media untuk mencapai tujuan tertentu. Kategori ini meliputi: transportasi (pesawat terbang, kapal, kereta api); komunikasi (TV, radio, telepon); akomodasi (seperti hotel dan restoran): dan rekreasi (bioskop dan taman wisata). Kedua, to consumer (human services), yaitu layanan yang ditujukan kepada konsumen.

\section{Pelayanan Publik}

Penggunaan istilah pelayanan publik (publik service) dianggap memiliki kesamaan arti dengan istilah pelayanan umum atau pelayanan masyarakat. Istilah publik berasal dari bahasa inggris publik yang berarti umum, masyarakat, negara. Kata publik sebenarnya sudah diterima menjadi bahasan Indonesia baku menjadi publik yang berarti umu, orang banyak, ramai. Pelayanan publik diartikan, pemberian pelayanan (melayani) keperluan orang atau masyarakat yang mempunyai kepentingan pada organisasi itu sesuai dengan aturan pokok dan tata cara yang telah ditetapkan.

Menurut keputusan Menpan Nomor 63 Tahun 2003, publik adalah : segala kegiatan pelayanan yang dilaksanakan oleh penyelenggara layanan publik sebagai upaya pemenuhan kebutuhan penerima pelayanan maupun pelaksanaan ketentuan peraturan perundangundangan. Dengan demikian pelayanan publik adalah pemenuhan keinginan dan kebutuhan masyarakat oleh penyelenggara negara. Negara didirikan oleh publik (masyarakat) tentu saja dengan tujuan agar dapat meningkatkan kesejahteraan masyarakat. adalah:

Sedangkan pelayanan publik menurut keputusan Menpan Nomor 63 Tahun 2003

"Segala bentuk pelayanan yang dilaksanakan oleh instansi pemerintah pusat, di daerah dan lingkungan Badan usaha Milik Negara atau Badan Usaha Milik Daerah dalam bentuk barang atau jasa baik dalam rangka upaya pemenuhan kebutuhan masyarakat maupun dalam rangka pelaksanaan ketentuan peraturan perundang-undangan".

Mengikuti definisi di atas, layanan publik atau pelayanan umum dapat didefenisikan sebagai : "Segala bentuk jasa pelayanan, baik dalam bentuk barang publik maupu jasa publik yang pada prinsipnya menjadi tanggung jawab dan dilaksanakan oleh instansi pemerintah di pusat, di daerah dan lingkungan Badan Usaha Milik Negara atau Badan Usaha Milik Daerah dalam rangka upaya pemenuhan kebutuhan masyarakat maupun dalam rangka pelaksanaan ketentuan peraturan perundang-undangan.

Moenir (2002:26), berpendapat bahwa pelayanan umum adalah : "Kegiatan yang dilakukan oleh seseorang atau sekelompok orang dengan landasan faktor materil melalui 
sistem, prosedur dan metode tertentu dalam rangka usaha memenuhi kepentingan orang lain sesuai dwngan haknya".

Dari pengertian pelayanan publik dalam keputusan Menpan Nomor 63 Tahun 2003, terkandung beberapa pengertian dasar sebagai berikut :

1. Pelayanan publik adalah segala kegiatan pelayanan yang dilaksanakan oleh penyelenggara pelayanan publik sebagai upaya pemenuhan kebutuhan penerima pelayanan maupun pelaksanaan ketentuan perundang-undangan.

2. Penyelenggara pelayanan publik adalah instansi pemerintah.

3. Instansi pemerintah adalah sebutan kolektif meliputi satuan kerja/satuan organisasi kementerian, departemen, lembaga pemerintah non departemen, kesekretariatan lembaga tertinggi dan tinggi Negara dan instansi pemerintah lainnya, baik pusat maupun daerah termasuk Badan Usaha Milik Negara, Badan Hukum Milik Negara dan Badan Usaha Milik Daerah.

4. Unit penyelenggara layanan publik adalah unit kerja pada instansi pemerintah secara langsung memberikan pelayanan kepada penerima pelayanan publik.

5. Pemberi pelayanan publik adalah [pejabat/pegawai instansi pemerintah yang melaksanakan tugas dan fungsi pelayanan publik sesuai dengan peraturan perundangundangan.

6. Penerima pelayanan publik adalah orang, masyarakat, instansi pemerintah dan badan hokum.

7. Biaya pelayanan publik adalah segala biaya (dengan nama atau sebutan apapun) sebagai imbal jasa atas pemberian pelayanan publik yang besaran dan tata cara pembayaran ditetapkan oleh pejabat yang berwenang sesuai peraturan perundang-undangan.

8. Indek kepuasan masyarakat adalah tingkat kepuasan masyarakat dalam memperoleh pelayanan yang diperoleh dari penyelenggara atau pemberi pelayanan sesuai harapan dan kebutuhan masyarakat.

Setiap penyelenggara pelayanan publik harus memiliki standar pelayanan dan dipublikasikan sebagai jaminan adanya kepastian bagi penerima pelayanan. Standar pelayanan merupakan ukuran yang dibakukan dalam penyelenggaraan pelayanan publik yang wajib ditaati, menurut keputusan Menpan Nomor 63 Tahun 2003, standar pelayanan sekurangkurangnya meliputi :

1. Prosedur pelayanan adalah prosedur pelayanan yang dibakukan bagi pemberi dan penerima pelayanan termasuk pengaduan.

2. Waktu dan penyelesaian adalah waktu penyelesaian yang ditetapkan sejak saat pengajuan permohonan sampai dengan penyelesaian pelayanan termasuk pengaduan.

3. Biaya pelayanan adalah biaya/tariff pelayanan termasuk rinciannya yang ditetapkan dalam proses pemberian pelayanan.

4. Produk pelayanan adalah hasil pelayanan yang akan diterima sesuai dengan ketentuan yang telah ditetapkan.

5. Sarana dan prasarana adalah penyediaan sara dan prasarana pelayanan yang memadai oleh penyelenggara pelayanan publik.

6. Kompetensi petugas pemberi layanan adalah kompetensi petugas pemberi layanan harus ditetapkan dengan tepat berdasarkan pengetahuan, keahlian, keterampilan, sikap dan perilaku yang dibutuhkan.

Ukuran keberhasilan penyelenggara pelayanan ditentukan oleh tingkat kepuasan penerima pelayanan. Kepuasan penerima pelayanan dicapai apabila penerima pelayanan memperoleh pelayanan sesuai dngan yang dibutuhkan dan diharapkan. Oleh karena itu, dalam kaitannya dengan tingkat kepuasaan masyarakat, keputusan Menpan Nomor 63 Tahun 2003 mengamanatkan agar setiap penyelenggara pelayanan secara berkala melakukan survey indeks kepuasan masyarakat.

Dari uraian di atas dapat disimpulkan bahwa sasaran dari manajemen pelayanan umum atau pelayanan publik adalah kepuasan. Meskipun sasaran itu sederhana tetapi untuk mencapainya diperlukan kesungguhan dan syarat-syarat yang seringkali tidak dilakukan. Hal ini berkaitan dengan masalah kepuasan yang tidak dapat diukur dengan pasti, paling hanya dapat 
dikenali dari beberapa sudut. Dalam hubungannya dengan pelayanan umum pengenalan kepuasaan seseorang, dalam hal ini pihak yang menerima layanan untuk mendapatkan haknya, ada semacam uuran tetapi relative yaitu apabila ia dapat menerima perlakuan dan hasil berupa hak dengan kegembiraan dan keikhlasan.

\section{Indeks Kepuasan Masyarakat}

Indeks kepuasan masyarakat adalah data dan informasi tentang tingkat kepuasan masyarakat yang diperoleh dari hasil pengukuran secara kuantitatif dan kualitatif atas pendapat masyarakat dalam memperoleh pelayanan dari aparatur penyelenggara pelayanan publik dengan membandingkan antara harapan dan kebutuhannya. Pada dasarnya setiap interaksi dengan pelanggan adalah sebuah bentuk dari layanan pelanggan. Bentuk interaksi tersebut bermacam-macam, bias lewat telepon, surat, email atau atap muka langsung. Semua bentuk kontak dengan pelanggan ini memikul tanggungjawab yang sama terhadap persepsi konsumen mengenai suatu bisnis dan tingkat kepuasan keseluruhan yang mereka rasakan ketika berhubungan dengan bisnis itu. Jadi layanan pelanggan adalah benar-benar tentang memuskan kebutuhan pelanggan dan melampaui harapan-harapan pelanggan.

Sebagai pelanggan kita semua memiliki harapan-harapan tertentu sebelum menggunakan suatu bisnis. Pemahaman tentang harapan-harapan ini akan sangat membantu dalam memberikan level layanan pelanggan terbaik kepada pelanggan. Ada banyak tipe-tipe harapan pelanggan yang dikemukakan para ahli dalam literature kualitas layanan dan kepuasan pelanggan yang dapat kita bagi dalam empat macam standar kinerja. Harapan pelanggan atas kinerja produk atau jasa akan berlaku sebagai standar perbandingan terhadap kinerja actual produk atau jasa. Empat macam harapan pelanggan tersebut (Wood, 2009:6) yaitu :

1. Enguitable performance/normative performance yaitu penilaian normatif yang mencerminkan kinerja yang seharusnya diterima seseorang atas biaya dan usaha yang telah dicurahkan untuk membeli dan mengonsumsi barang atau jasa tertentu.

2. Ideal performance yaitu tingkat kinerja optimum atau ideal yang diharapkan oleh seorang pelanggan.

3. Expected performance yaitu tingkat kinerja yang diperkirakan/disukai pelanggan. Tipe ini adalah yang paling banyak digunakan dalam penelitian kepuasan/ketidakpuasan pelanggan.

4. Adequate expectation/minimum tolerable yaitu tingkat kinerja produk atau jasa terendah yang dapat ditoleransi pelanggan.

Manfaat memberikan layanan pelanggan yang luar biasa sebenarnya cukup sederhana, jika layanan kepada pelanggan baik, pelanggan akan puas dan mereka akan kembali dan akan memberitahu teman-temannya dan teman-temannya juga akan memberitahu teman-teman mereka yang lain begitu seterusnya.

Pada prinsipnya pelayanan swasta berbeda dengan pelayanan publik. Namun demikian terdapat persamaan di antara keduanya, yaitu :

1. Keduanya berusaha memenuhi harapan pelanggan dan mendapatkan kepercayaannya.

2. Kepercayaan pelanggan adalah jaminan atas kelangsungan hidup organisasi.

Karakteristik khusus dari pelayanan publik yang membedakannya dari pelayanan swasta adalah :

1. Sebagian besar layanan pemerintah berupa jasa dan barang tak nyata. Misalnya perjanjian, sertifikat, peraturan, informasi keamanan, kertertiban, kebersihan, transportasi dan lain sebagainya.

2. Selalu terkait dengan jenis pelayanan-pelayanan yang lain dan membentuk sebuah jalinan sistem pelayanan yang berskala regional bahkan nasional. Contohnya dalam hal pelayanan transportasi.

3. Pelanggan internal cukup menonjol, sebagai akibat dari tatanan organisasi pemerintah yang cenderung birokratis. Dalam dunia pelayanan berlaku prinsip utamakan pelanggan eksternal lebih dari pelanggan internal. Namun situasi nyata dalam hal hubungan antar lembaga pemerintahan sering memojokkan petugas pelayanan agar mendahulukan pelanggan internal. 
4. Efisiensi dan efektivitas pelayanan akan meningkat seiring dengan peningkatan mutu pelayanan. Semakin tinggi mutu pelayanan bagi masyarakat, maka semakin tinggi pula kepercayaan masyarakat kepada pemerintah. Dengan demikian akan semakin tinggi pula peran serta masyarakat dalam kegiatan pelayanan.

5. Masyarakat secara keseluruhan diperlakukan sebagai pelanggan tidak langsung, yang sangat berpengaruh kepada upaya-upaya pengembangan pelayanan. Misalnya desakan untuk memperbaiki pelayanan oleh polisis bukan dilakukan oleh hanya pelanggan langsung (mereka yang pernah mengalami gangguan keamanan saja), akan tetapi juga oleh seluruh lapisan masyarakat.

6. Tujuan akhir dari pelayanan publik adalah terciptanya tatanan kehidupan masyarakat yang berdaya guna untuk mengurus persoalannya masing-masing.

Dalam upaya meningkatkan kualitas pelayanan pmerintah kepada masyarakat, kementerian pendayagunaan aparatur negara menetapkan kebijakan tentang pedoman umum penyusunan indeks kepuasan masyarakat (IKM) terhadap unit pelayanan instansi pemerintah. Kebijakan pemerintah untuk mengembangkan indeks kepuasan masyarakat dalam kaitannya dengan penyelenggaraan pelayanan diatur dalam keputusan Menpan Nomor 25 Tahun 2004.

Kebijakan pemerintah untuk mengembangkan indeks kepuasan masyarakat (IKM) dalam kaitannya dengan penyelenggaraan pelayanan diatur dalam keputusan Menpan Nomor 25 Tahun 2004 tanggal 24 februari 2004 Tentang Pedoman Umum Penyusunan Indeks Kepuasan Masyarakat Unit Pelayanan Instansi Pemerintah. Beberapa pengertian umum atau defenisi yang dipakai dalam KEPMENPAN ini antara lain adalah sebagai berikut :

1. Indeks kepuasan masyarakat (IKM) adalah data dan informasi tentang tingkat kepuasan masyarakat yang diperoleh dari hasil pengukuran secara kuantitatif dan kualitatif atas pendapat masyarakat dalam memperoleh pelayanan dari aparatur penyelenggara pelayanan publik dengan membandingkan antara harapan dan kebutuhannya.

2. Penyelenggara pelayanan publik adalah instansi pemerintah.

3. Instansi pemerintah adalah instansi pemerintah pusat dan pemerintah daerah termasuk BUMN/BUMD dan BHMN.

4. Pelayanan publik adalah segala kegiatan pelayanan yang dilaksanakan oleh penyelenggara pelayanan publik sebagai upaya pemenuhan kebutuhan penerima pelayanan, maupun dalam rangka pelaksanaan ketentuan peraturan perundang-undangan.

5. Unit pelayanan publik adalah unit kerja/kantor pelayanan pada instansi pemerintah termasuk BUMN/BUMD dan BHMN, yang secara langsung maupun tidak langsung memberi pelayanan kepada penerima pelayanan.

6. Pemberi pelayanan publik adalah pegawai instansi pemerintah yang melaksanakan tugas dan fungsi pelayanan publik sesuai dengan peraturan perundang-undangan.

7. Penerima pelayanan publik adalah orang, masyarakat, lembaga instansi pemerintah dan dunia usaha yang menerima pelayanan dari aparatur penyelenggara pelayanan publik.

8. Kepuasan pelayanan adalah hasil pendapat dan penilaian masyarakat terhadap kinerja pelayanan yang diberikan oleh aparatur penyelenggara pelayanan publik.

9. Biaya pelayanan publik adalah segala biaya (dengan nama atatu sebutan apapun) sebagai imbal jasa atas pemberian pelayanan publik, yang besaran dan tata cara pembayarannya ditetapkan oleh pejabat yang berwenang sesuai ketentuan peraturan perundang-undangan.

10. Unsur pelayanan adalah faktor atau aspek yang terdapat dalam penyelenggaraan pelayanan kepada masyarakat sebagai variabel penyususan.

11. Responden adalah penerima pelayanan publik yang pada saat pencacahan sedang berada di lokasi unit pelayanan atau yang pernah menerima pelayanan dari aparatur penyelenggara pelayanan.

\section{Kerangka Analisis}




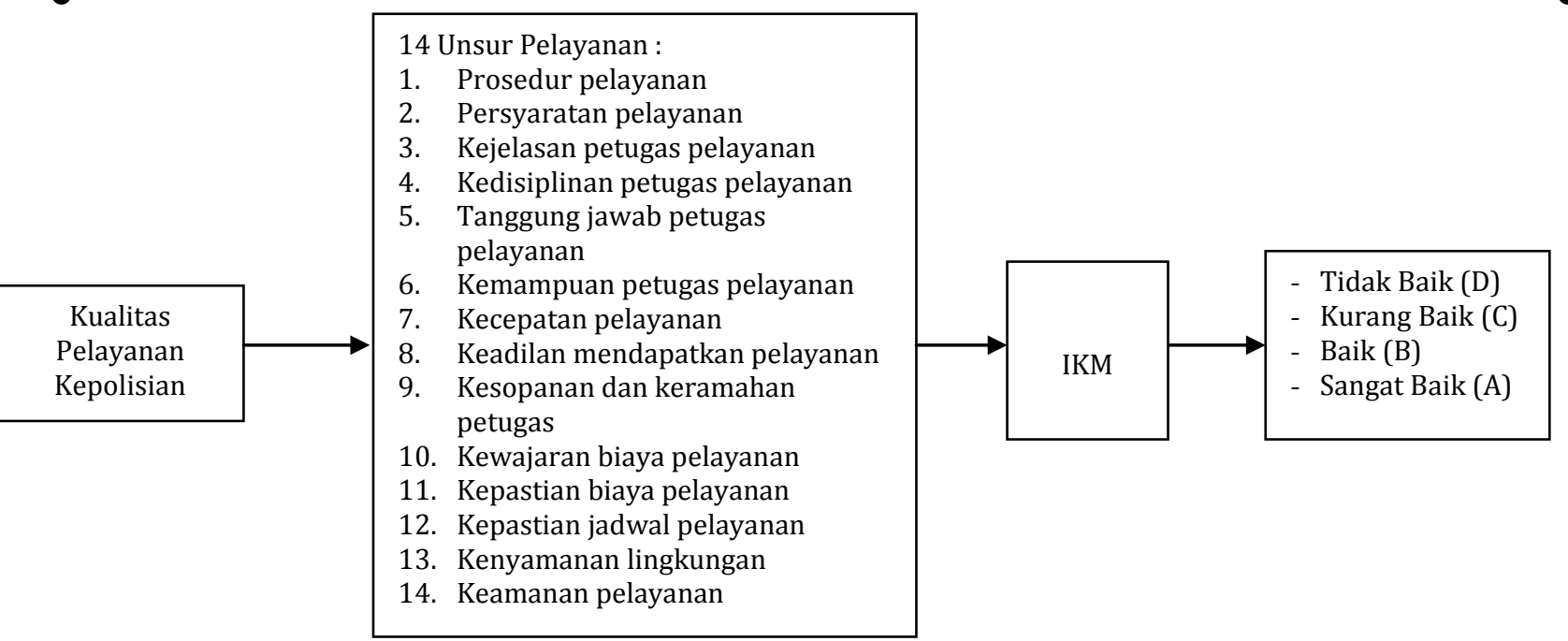

Gambar 1. Kerangka Analisis

\section{HASIL DAN PEMBAHASAN Indeks Kepuasan Masyarakat (IKM)}

Berdasarkan data dari lampiran 1 dapat diketahui nilai rata-rata per unsur layanan sesuai dengan ketentuan Men.Pan No KEP/25/M.PAN/2/2004 dengan rumus sebagai berikut :

Nilai rata-rata per unsure layanan $=$

Nilai unsur layanan

Jumlah Responden

Berdasarkan Tabel 3 dapat dilihat bahwa nilai rata-rata per unsur pelayanan yang paling tinggi adalah pada tanggung jawab petugas pelayanan dan kemampuan petugas pelayanan yang diberikan oleh Direktorat Intelijen Keamanan Polisi Daerah Bengkulu yaitu nilai unsur 2,77. Hal ini menunjukkan bahwa pelanggan sudah mendapatkan pelayanan yang baik dari Direktorat Intelijen Keamanan Polisi Daerah Bengkulu.

Tabel 3. Nilai Unsur Per Layanan

\begin{tabular}{|c|c|c|c|c|c|}
\hline No & Unsur Layanan & $\begin{array}{l}\text { Nilai Unsur } \\
\text { Layanan } \\
\text { (a) }\end{array}$ & $\begin{array}{c}\text { Jumlah } \\
\text { Responden } \\
\text { (b) }\end{array}$ & $\begin{array}{c}\text { Nilai Rata-Rata } \\
\text { Per Unsur } \\
\text { Layanan }(\mathbf{c}=\mathbf{a} / \mathbf{b})\end{array}$ & $\begin{array}{l}\text { Kualitas } \\
\text { Pelayanan }\end{array}$ \\
\hline 1 & Prosedur pelayanan & 406 & 150 & 2,71 & Baik \\
\hline 2 & Persyaratan pelayanan & 384 & 150 & 2,56 & Baik \\
\hline 3 & Kejelasan petugas pelayanan & 415 & 150 & 2,77 & Baik \\
\hline 4 & Kedisplinan petugas pelayanan & 395 & 150 & 2,63 & Baik \\
\hline 5 & $\begin{array}{l}\text { Tanggung jawab petugas } \\
\text { pelayanan }\end{array}$ & 406 & 150 & 2,71 & Baik \\
\hline 6 & Kemampuan petugas pelayanan & 406 & 150 & 2,71 & Baik \\
\hline 7 & Kecepatan pelayanan & 378 & 150 & 2,52 & Baik \\
\hline 8 & $\begin{array}{l}\text { Keadilan Mendapatkan } \\
\text { pelayanan }\end{array}$ & 399 & 150 & 2,66 & Baik \\
\hline 9 & $\begin{array}{l}\text { Kesopanan dan keramahan } \\
\text { petugas }\end{array}$ & 388 & 150 & 2,59 & Baik \\
\hline 10 & Kewajaran biaya & 377 & 150 & 2,51 & Baik \\
\hline 11 & Kepastian biaya & 361 & 150 & 2,41 & Kurang Baik \\
\hline 12 & Kepastian jadwal & 363 & 150 & 2,42 & Kurang Baik \\
\hline 13 & Kenyamanan lingkungan & 376 & 150 & 2,51 & Baik \\
\hline 14 & Keamanan dalam pelayanan & 365 & 150 & 2,43 & Baik \\
\hline
\end{tabular}

Sumber : Hasil Olah Data Kuisioner, 2013. 
Sedangkan nilai rata-rata per unsur yang paling rendah yaitu pada kepastian biaya yaitu sebesar 2,41 . Hal ini berarti masih banyak pelanggan yang beranggapan bahwa pelayanan yang diberikan oleh Direktorat Intelijen Keamanan Polisi Daerah Bengkulu adalah kurang baik. Untuk mencari nilai rata-rata tertimbang per unsur pelayanan, maka jumlah nilai rata-rata per unsur layanan dikalikan dengan 0,071 (sesuai dengan ketentuan Men.Pan Nomor KEP/25/M.PAN/2/2004 sebagai nilai bobot rata-rata tertimbang. Perhitungan tersebut dapat dilihat pada Tabel 4.

Tabel 4. Nilai Rata-Rata Tertimbang Per Unsur Layanan

\begin{tabular}{|c|c|c|c|c|}
\hline No & Unsur Layanan & $\begin{array}{c}\text { Nilai Rata-Rata } \\
\text { Pelayanan } \\
\text { (a) }\end{array}$ & $\begin{array}{l}\text { Nilai Bobot } \\
\text { Tertimbang } \\
\text { (b) }\end{array}$ & $\begin{array}{l}\text { Nilai Rata-Rata } \\
\text { Tertimbang } \\
\text { (c= a x b) }\end{array}$ \\
\hline 1 & Prosedur pelayanan & 2,71 & 0,071 & 0,19 \\
\hline 2 & Persyaratan pelayanan & 2,56 & 0,071 & 0,18 \\
\hline 3 & Kejelasan petugas pelayanan & 2,77 & 0,071 & 0,20 \\
\hline 4 & Kedisplinan petugas pelayanan & 2,63 & 0,071 & 0,19 \\
\hline 5 & Tanggung jawab petugas pelayanan & 2,71 & 0,071 & 0,19 \\
\hline 6 & Kemampuan petugas pelayanan & 2,71 & 0,071 & 0,19 \\
\hline 7 & Kecepatan pelayanan & 2,52 & 0,071 & 0,18 \\
\hline 8 & Keadilan Mendapatkan pelayanan & 2,66 & 0,071 & 0,19 \\
\hline 9 & Kesopanan dan keramahan petugas & 2,59 & 0,071 & 0,18 \\
\hline 10 & Kewajaran biaya & 2,51 & 0,071 & 0,18 \\
\hline 11 & Kepastian biaya & 2,41 & 0,071 & 0,17 \\
\hline 12 & Kepastian jadwal & 2,42 & 0,071 & 0,17 \\
\hline 13 & Kenyamanan lingkungan & 2,51 & 0,071 & 0,18 \\
\hline 14 & Keamanan dan pelayanan & 2,43 & 0,071 & 0,17 \\
\hline \multicolumn{4}{|c|}{ Nilai Indeks Kepuasan Masyarakat (IKM) } & 2,56 \\
\hline
\end{tabular}

Sumber : Hasil Olah Data Kuisioner, 2013.

Dari Tabel 4 dapat dilihat bahwa nilai rata-rata tertimbang untuk unsur pelayanan pada kejelasan petugas pelayanan, memiliki nilai tertinggi yaitu 0,20 , sedangkan nilai terendah 0,17 terdapat pada kepastian jadwal pelayanan, kepastian biaya, serta keamanan dan kenyamanan pelayanan kemudian nilai rata-rata tertimbang sebesar 0,18 terdapat pada kenyamanan lingkungan, persyaratan pelayanan, kecepatan pelayanan, kesopanan dan keramahan petugas serta kewajaran biaya, nilai rata-rata tertimbang sebesar 0,19 terdapat pada prosedur pelayanan, kedisiplinan petugas pelayanan, tanggungjawab petugas pelayanan, kemampuan petugas pelayanan, serta keadilan mendapatkan pelayanan.

Untuk mendapatkan nilai indeks kepuasan masyarakat terlebih dahulu dicari nilai indeks unit pelayanan yaitu nilai rata-rata tertimbang dari 14 unsur pelayanan yang dijumlahkan. Setelah itu dikalikan dengan nilai dasar yaitu 25. Sesuai dengan ketentuan Men.Pan Nomor KEP/25/M.PAN/2/2004 bahwa nilai indeks unit pelayanan tersebut dikalikan dengan nilai dasar sebesar 25, sehingga didapat indeks kepuasan masyarakat, yaitu :

$\mathrm{IKM}=\mathrm{IM}$ Unit Pelayanan $\mathrm{x}$ Nilai Dasar

$$
\begin{aligned}
& =2,56 \times 25 \\
& =63,9
\end{aligned}
$$

Dari perhitungan tersebut, maka diketahui bahwa nilai IKM pada Direktorat Intelijen Keamanan Polisi Daerah Bengkulu adalah "baik" karena nilai tersebut berada diantara interval nilai 62,51 - 81,25 yang berada pada mutu pelayanan B (baik).

\section{Pembahasan}

Berdasarkan hal di atas, maka dapat disimpulkan bahwa dari penyebaran kuisioner yang diberikan kepada 150 orang responden Direktorat Intelijen Keamanan Polisi Daerah Bengkulu mempunyai pendapat bahwa pelayanan yang diberikan oleh Direktorat Intelijen 
Keamanan Polisi Daerah Bengkulu adalah baik, yang bisa dilihat dalam 14 unsur pelayanan yang tertuang di dalam kuisioner.

Kejelasan petugas pelayanan yang diberikan kepada masyarakat yang datang ke Direktorat Intelijen Keamanan Polisi Daerah Bengkulu tidak mempersulit, baik untuk pendaftaran, pembayaran maupun dalam prosedur pelayanan yang dihadapi masyarakat tidak memakan waktu yang lama dalam penyelesaiannya.

Para petugas pelayanan mempunyai kejelasan, bukanlah sembarang orang melainkan petugas yang telah mengikuti pelatihan dan pembekalan serta memiliki keterampilan yang diberikan oleh Direktorat Intelijen Keamanan Polisi Daerah Bengkulu sehingga kemampuan dalam memberikan pelayanan kepada si pemohon bisa dilakukan dengan baik, meskipun menurut respon dari si pemohon bahwa masih ada terdapat kurangnya disiplin petugas pada Direktorat Intelijen Keamanan Polisi Daerah Bengkulu dalam melayani si pemohon.

Dalam melakukan pelayanan kepada si pemohon, para petugas harus bertanggung jawab dan tidak membedakan antar masyarakat yang satu dengan masyarakat yang lainnya, meskipun berdasarkan hasil kuisioner didapati bahwa pelayanan yang diberikan oleh para petugas pada Direktorat Intelijen Keamanan Polisi Daerah Bengkulu. Dalam hal kepastian jadwal pelayanan, kepastian biaya, dalam melakukan pelayanan dinilai kurang baik oleh responden ketimbang unsur pelayanan lainnya, hal ini mungkin dikarenakan banyaknya orang yang datang untuk membuat SKCK dan surat perizinan adanya keramaian dari Direktorat Intelijen Keamanan Polisi Daerah Bengkulu sehingga ada beberapa masyarakat yang kurang puas atas pelayanan yang diberikan. Sedangkan dari sisi kesopanan dan keramahan petugas serta keamanan dan kenyamanan pelayanan dalam melayani masyarakat pada Direktorat Intelijen Keamanan Polisi Daerah Bengkulu sudah dinilai baik oleh pelanggan.

Berdasarkan penyebaran kuisioner kepada para responden, maka dapat diketahui pendapat para responden bahwa Direktorat Intelijen Keamanan Polisi Daerah Bengkulu sudah memberikan kenyamanan lingkungan, persyaratan pelayanan, kecepatan pelayanan, kesopanan dan keramahan petugas serta kewajaran biaya terhadap pelayanan yang diberikan oleh Direktorat Intelijen Keamanan Polisi Daerah Bengkulu itu sendiri. Begitu juga dengan prosedur pelayanan, kedisiplinan petugas pelayanan, tanggungjawab petugas pelayanan, kemampuan petugas pelayanan, serta keadilan mendapatkan pelayanan dinilai sudah baik oleh pelanggan. Dengan demikian maka bisa dikatakan bahwa secara rata-rata kualitas pelayanan jasa yang diberikan oleh Direktorat Intelijen Keamanan Polisi Daerah Bengkulu sudah baik, tetapi memang masih ada bagian-bagian yang kurang, sehingga untuk ke depannya pihak Direktorat Intelijen Keamanan Polisi Daerah Bengkulu itu sendiri perlu meningkatkan dan memperbaiki lagi kualitas pelayanan terhadap masyarakat.

\section{Kesimpulan}

1. Nilai rata-rata per unsur pelayanan yang paling tinggi adalah pada kejelasan petugas pelayanan yang diberikan oleh Direktorat Intelijen Keamanan Polisi Daerah Bengkulu yaitu dengan nilai unsur pelayanan sebesar 2,77 dan nilai rata-rata per unsur pelayanan yang paling rendah yaitu pada kepastian biaya sebesar 2,41.

2. Nilai IKM pada Direktorat Intelijen Keamanan Polisi Daerah Bengkulu sebsar 63,9 yang berarti bahwa kinerja unit pelayanan pada Direktorat Intelijen Keamanan Polisi Daerah Bengkulu adalah "baik", karena nilai tersebut berada diantara 62,51 - 81,25 yang berada pada mutu pelayanan B (baik).

\section{Saran}

1. Walaupun dari hasil penelitian menunjukkan bahwa IKM Direktorat Intelijen Keamanan Polisi Daerah Bengkulu 63,9 yang berarti bahwa kinerja unit pelayanan pada Direktorat Intelijen Keamanan Polisi Daerah Bengkulu adalah "baik", karena tersebut berada diantara 62,51 - 81,25 yang berada pada mutu pelayanan B (baik), tetapi nilai IKM tersebut mendekati batas bawah kategori mutu pelanan B (baik) oleh karena itu diharapkan agar 
pelayanan yang diberikan oleh Direktorat Intelijen Keamanan Polisi Daerah Bengkulu menambah lagi kualitas dari sarana dan prasarana yang telah ada, serta lebih meningkatkan lagi kinerja pegawai dalam memberikan pelayanan kepada masyarakat.

2. Direktorat Intelijen Keamanan Polisi Daerah Bengkulu perlu melakukan perbaikan pada beberapa unsur pelayanan, antara lain:

1) Kepastian Biaya Pelayanan:

- $\quad$ Meletakkan setiap informasi biaya pelayanan di tempat yang strategis.

2) Kepastian Jadwal Pelayanan

- Melakukan pengawasan memantau jam buka dan tutup pelayanan.

\section{DAFTAR PUSTAKA}

Harsono, Yogo Jatmiko. 2012. Kualitas Pelayanan Perpanjangan Surat Izin Mengemudi (SIM) Di Unit Pelayanan SIM Keliling Satlantas Polrestabes Surabaya Berdasarkan Indeks Kepuasan Masyarakat (IKM). Universitas Pembangunan Nasional. Surabaya

Hasibuan, S.P. Malayu. 2005. Dasar-Dasar Perbankan. Jakarta. Bumi Aksara.

Keputusan Menteri Pendayagunann Aparatur Negara Nomor 25 Tahun 2004 Tentang Pedoman Umum Penyusunan Indeks kepuasan Masyarakat Unit Pelayanan Instansi Pemerintah.

Keputusan Menteri Pendayagunann Aparatur Negara Nomor 63 Tahun 2003 Tentang Pedoman Umum Penyelenggaraan Pelayanan Publik.

Moenir. H.A.S. 2002. Manajemen Pelayanan Umum Di Indonesia. Jakarta. Bumi Aksara.

Sinambela, Lijan Poltak. 2010. Reformasi Pelayanan Publik Teori, Kebijakan dan Implementasi. Jakarta. Bumi Aksara.

Sugiyono. 2010. Statistik Non Parametris. Bandung. CV. Alfabeta.

Supranto, J. 2002. Statistik, Teori dan Aplikasi. Jakarta. Erlangga.

Tjiptono, Fandy. 2008. Service Management. Yogyakarta. Andi Offset.

Wood, Ivone. 2009. Layanan Pelanggan. Yogyakarta. Graha Ilmu. 